lake and forms the tongue of Hurden, about two miles in length and less than half a mile in width. The peculiarly coarse sand and fine gravel which is extensively quarried in this locality and is found at no other point of the lake, affords unmistakable evidence of this being the former outlet of the river. In the course of subsequent dislocations in the upper strata, the old bed was barred, and the river scooped out a new bed through the molasse and nagelfluh of the Albis range of hills, parallel and in close proximity to the lake. The Sihl falls into the Limmat about a mile below the ontflow of the latter from the lake, and has an average flow of about one million tons per day, equal to one-eighth of that of the Limmat, although, when in flood, it exceeds at times the mean water volume of the latter. It follows that when the drainage area of the Sihl still formed part of that of the lake of Zurich, the latter must have covered a much larger superficial area than it does now, and that this area had not only a higher level but must have probably extended some twelve miles below Zurich, viz. to the neighbourhood of Baden, where the valley abruptly narrows into a defile of about two miles in length, throngh which the Limmat rushes to its confluence with the Aare and Reuss at Turgi with a considerable fall.

\title{
INOTIOFS OF MFIMOIRS.
}

\section{I.-The Antarctic Continent.}

TWDER the title of "The Chatham Islands: their relation to a former Antarctic Continent," Mr. Henry O. Forbes, F.R.G.S., read a most interesting paper before the Royal Geographical Society, illustrated by maps and figures, in which he gave an admirable account of the Chatham Islands, which lie on the extreme verge of the $180^{\circ}$ meridian and 500 miles east of Port Lyttelton, in the south island of New Zealand. Wharekauri, the largest of the group, is 36 miles long, in an east and west direction, and 27 miles broad, from north to south; while Rangiauria, the next biggest, is 9 miles long by 6 miles wide. Since 1840, when they were visited and described by Dr. Dieffenbach, on behalf of the New Zealand Company (see Journ. R. Geogr. Sec. vol. xi. 1841), "now half a century ago, considerable changes have taken place in the outward aspect of the islands. The more or less extensive forests that grew on many parts of the land have to a great extent disappeared to make place for sheep pastures or cultivated fields. The Morioris, or original inhabitants of the Archipelago, whose ranks first thinned by an incursion of Maoris from New Zealand, who for the express purpose of feeding on them had themselves transported thither, have all but vanished, and only a family or two now remain of a race that within the next decade or so will have to be numbered with the Tasmanians and with the wonderful birds that once inhabited with them this isolated spot of land. The Maoris, who since that incursion have possessed, by right of seizure, I suppose, a considerable part of the land, are also fast decreasing in number through disease and drink. 
The greater part of the islands, therefore, is owned by European run-holders and stocked with sheep and a few cattle."

After describing the flora of the Islands, and the wealth of Ocean birds which make their residence here, or come to these shores in the breeding-season, Mr. Forbes tells us-

"The whole surface of the islands, especially Wharekauri and Rangiauria, is covered with a bed of peat in places over 40 feet in depth-deeper in the northern arm than in the southern-traversable in safety only by those acquainted with the country; for to the inexperienced eye there seems in most places no difference in the surface which can carry with safety both horse and rider, and that on which the lightest-footed pedestrian could not venture without being engulfed. The surface of some of the larger and wetter depressions in the ground was covered with a brilliant-coloured carpet of luxuriant mosses, emitting an aromatic fragrance, spread out in artless undesigned parterres of rich commingled green, yellow, and purple, and endless shades of these, warning the traveller of the existence of dangerous bogs beneath, and brightening miles of treeless moorland, which, but for these floating gardens, would be uninviting and uninteresting. In many places all over the island this great peat moss is on fire, and has for years been smouldering undergronnd, or burning in the exposed faces of the great pits which have now been burnt out. Dr. Dieffenbach mentions their existence at his visit in 1840 , and states that the combustion had begun before 1834, and 'may indeed be traced to a much earlier period, and, in consequence, the soil in the neighbourhood is gradually sinking.' 'These fires, as far as I could gather, had been burning in one part or another of the island ever since Dieffenbach's visit. Whether the soil has been lit accidentally or on purpose, or has spontaneously taken fire throngh the decomposition of the peat and lignite, I could not ascertain. A peculiarity in the main island that strikes the visitor very early is the occurvence of many lakes and tarns. These lakes are, for the most part, on the eastern side, at the back of the low hills facing Petre Bay. The largest is 15 miles long, over 40 miles in circumference, and about $10 \frac{1}{2}$ miles at its widest part; and, therefore, occupies a large portion of the entire area of the island. Some of these tarns occur even on the highest part of the southern highlands."

Mr. Forbes's main object in visiting Chatham Islands was to discover the remains of a bird, some bones of which had been sent to New Zealand, and which opened up problems of geographical distribution of the highest interest. He writes :-

"Within a few days of my arrival, I had the satisfaction of disentombing from their ancient burial ground in the sand-hills of the Waitangi beach, the complete head and the greater part of the skeleton, certainly all important bones, of the bird to which the bead belonged. Associated with them were also those of a tall, extinct coot, and a large raven of an ancient type. I was thus able to confirm my doubtful identification of the bones, that the bird which in ancient days had lived in the Chatham Islands, 
was no other than a species of Aphanapteryx, a large and remarkable member of the rail family, which was contemporary with the celebrated dodo in the Island of Mauritius. That island had been till then the only place in the world where the Aphanapteryx was known to exist, and where it had with the dodo preserved its fading race down to about two hundred years ago, when both of these groups passed away and perished for ever from among living things. In the Chatham Islands I found the remains of the Aphanapteryx in kitchen middens of the Morioris, showing that in this region of the world also it had survived down to comparatively recent date, just as the moa had in New Zealand. To find bones of this bird was, therefore, the main object of my visit to the Chatham Islands, but I had in view also to search for evidences of the former existence there of the moa, the apteryx and the weka, characteristic birds of the New Zealand fauna, and to indicate the value and importance to natural and to geographical science, of their occurrence in this island, is the chief reason of my paper to-night."

"Deduced from the study of the distribution of species, it has come to be an accepted law that, "Whenever we find that a considerable number of the mammals (or what is practically the same thing, of flightless birds) of two countries exhibit distinct marks of relationship, wo may bo sure that an actual land connection, or at all events an approach to within a very few miles of each other, has at one time existed' (Wallace, 'Island Life,' 2nd ed. p. 74). Now, besides this remarkable Aphanapteryx, $I$ gathered on the Chatham Islands the bones of other birds now extinct there, but identical with species now living in New Zealand, and some of them characteristic of that island, such as the $K e a$, that peculiar parrot which has so changed its diet within recent years that forsaking fruits, it attacks and kills the sheep by eating through their backs into their vital organs; as well as the flightless woodhen, a species apparently identical with that of South Island (Ocydromus australis), a species of owl (Glaucidium Nove Z landia) and the smaller of the two species of New Zaaland hawk. In addition to these I obtained a species of swan which once lived (though now extinct) in New Zealand; and the tuatara, a curious and ancient form of lizard absolutely confined to the main group. The occurrence in the Chatham Islands of these species, some of which, like the flightless wood-hen, and the Kea anong birds and the tuatura lizard, which could not have crossed the intervening 500 miles of sea with the organs of locomotion they possess, proves that the Chatham Islands must have had at one time a continuous land connection with New Zealand. Its geological structure shows it to be a continental island, for though essentially volcanic, it possesses sedimentary rocks of palæozoic, secondary, and tertiary age, and its fora, which is most closely related to that of its larger neighbours, confirms this opinion as well as the shallowness of the intervening sea where the whalers it is said found soundings.

Confined now to one of the smaller, though once widely spread 
over the whole of the Chatham Islands, lives a flightless species of rail of the genus (Cabalus) kin to the woodbens, but which is quite unknown in New Zealand, but strangely enough appears again in Lord Howe's Island, far to the north-west, in the Tasman Sea. On the other hand, in the Antipodes, the Auckland, the Macquarrie, and the Campbell Islands, far to the south, we have birds such as the New Zealand woodhen, and a parrot belonging to the red-headed group (Cyanorhamphus) common both to the mainland and to the Chatham Islands, as well as many plants common to one or more of these southern islands, and to New Zealand or the Chatham Islands, proclaiming that these island specks are but the fragments protruding above the surface of the sea of a continent or continental island now broken up, and all but totally covered.

It seems pretty certain therefore that 'the Bampton shoal west of New Caledonia, and Lord Howe's Island further south,' and perhaps also New Caledonia and Fiji, formed the northern and western limits of this former extensive continental island, which almost certainly also extended east to the Chatham Islands, and most probably south and east to the Macquarrie and the Antipodes Islands which we may name Antipodea.

Now turning for a little to another quarter of the globe, to the region of the Mascarene Islands, we find that François Leguat, the French Huguenot emigrant from Europe to South Africa, who lived in several of these islands, and recorded with great exactness all that he suffered and all that he saw in his "Voyage." $\mathrm{He}$ specially describes the solitaire, a great flightless pigeon, and also a woodhen, or gelinote, with a red beak and red borders to its eyes. Remains of this bird have been discovered along with those of the solitaire, and have been determined to belong to a great species of rail, nearly related to the woodhens of Now Zealand. From its hostility to red the generic name of Erythromachus has been applied to it.

The Island of Mauritius, 95 miles to the south-west, was inhabited by the great dodo (Didus ineptus), which was also a gigantic flightless pigeon, living on the ground. It was a very near relative of the solitaire, as was finally proved by an examination of the large collection of its bones received in Europe in 1866, among which there were several of another bird then unknown, and which continued to be so till the year 1868, when Herr von Frauenfeld discovered in the library of the Emperor of Austria the picture of a remarkable bird, a tall crane or woodhen, so closely agreeing with the description of the gelinote given by Leguat as to leave no doubt as to its identity. The bones found mixed with those of the dodo turned ont unquestionably to belong to this fine woodhen, which was named Aphanapteryx. Both birds, however, were of the closest kin to each other, and must have had a common ancestor; but their nearest relatives elsewhere are the wekas, or woodhens, of New Zealand. At the present day there are no birds in either Rodriguez or Mauritius nearly related to the Ocydromine group of 
the rails. Professor Newton also and his brother, Sir Edward, consider it 'impossible on any other reasonable supposition than that of a common ancestry to account for the distribution of the animal forms that they present. These authors are compelled to the belief that there was once a time when Rodriguez, Mauritius, Bourbon, Madagascar, and the Seychelles were connected by dry land which we may name Mascarenia, and that that time is sufficiently remote to have permitted the descendants of the original inhabitants of this now submerged continent to become modified into the many representative forms which are now known. . . . That the solitaire of Rodriguez and the dodo of Mauritius, much as they eventually came to differ, sprang from one and the same stock, seems a deduction so obvious that the authors can no more conceive anyone fully acquainted with the facts of the case hesitating about its adoption' ('Voyage of François Leguat,' vol. ii. p. 356-Hakluyt Society, 1891).

Un comparing the bones of the Aphanapteryx brought from the Chatham Islands with thoso of the Mauritius bird, I have found them to be so closely related as to be almost inseparable. Indeed, these bones from Wharekanri and Mauritius, over $120^{\circ}$ of Iongitude apart, are more nearly related to each other than the Erythromachus of Rodriguez (an island of its own archipelago, only 95 miles distant) is with the Aphanapteryx of Mauritius.

The question arises how came they to inhabit such widely separated regions? There is only one deduction: the members of the genus must have reached their respective homes by some con- tinuous land connection between the two places. In order, however, to make as clear as possible the route by which Mr. Forbes believed these descendants of a common ancestor reached habitats so far apart, he discussed the distribution of life in other regions of the hemisphere.

In the sonthern regions of the great continents, in the southern part of South America, in South Africa, in Australia, and in New Zealand, we have forms, either still living or now extinct, that are so closely related as to indicate that they have sprung from a common ancestor. In New Zealand there occur the remains of the moa, which stood over 10 feet in height, a member of the ancient family of the ostriches. It lived down to comparatively recent times and goes back to about the newer Pliocene or Pleistocene age. We have also here a somewhat aberrant form of the same family, the kiwi, or apteryx, still living. In Australia there existed a now extinct genus of the same family, the Dromornis; and two genera alive, the emu and the cassowary--the latter extending into New Guinea and some of the surrounding islands. In Madagascar we find in a fossil state the bones of a large species of the same group, the Epyornis; I have lately examined specimens of its bones recently received in the British Museum, whose similarity to those of the moa is so great that if they had been discovered in New Zealand they would, I believe, undoubtedly have been referred to a species of moa. In Africa we have the aberrant ostrich. While in 
South America, where the rheas occur, there has lately been discovered in the 'Tertia $y$ of Patagonia the remains of great flightless birds belonging to the Struthionide. This family is, therefore, practically confined to the southern hemisphere with few exceptions. Again, the fami $y$ of the Trogons is confined almost entirely to regions south of $t$ e equator. The penguins (Spheniscide) form a group still more losely restricted to Southern latitudes. Two ancient forms, Palceudyptes, Palcospheniscus, are known in the early Tertiaries of New Zealand and of Patagonia. They now range from Sonth Ameriva, South Africa, Australia, and New Zealand, to the Antarctic Islands. To the latter, i.e., the Falkland, the Crozet, and Kerguelen Islands, the family of the Chionide, a peculiar group of white birds related to the plovers, is also restricted. The great group of the parrots (Psittacomorpha) have, as pointed ont by Professor Huxley long ago, related, but very distinct families, in Australasia and in South America; they are feebly represented in India and South Africa, and have only a straggler here and there in North America. They are essentially a southern group.

'Turning to another section of the animal kingdom, we find wonderfully developed in Australia, and in New Guinea, and some of the neighbouring islands, the marsupials, or kangaroos and wombats, a group occurring nowhere else except in South America ; but the marsupials living now in Australia are not very nearly allied to those in Sonth America. In the Pliocene age, however, there lived in East Australia gigantic forms of the family, the Diprotodon, the Nototherium, the marsupial lion (Thylacoleo), and others; and quite recently remains of the genera Prothylacinus, Amphiproviverm, closely related to the Tasmanian Devil (Thylacinus), and to other Dasyuride of both Tasmania and Australia, have been discovered in the Eocene of Patagonia.

Another very extraordinary group (the Edentata), the ant-eaters, sloths, and armadillos, now live in the southern parts of South America. In more ancient times the order was represented by still more bizarre forms, such as the Glyptodon, the Mylodon, and the Megntherium. In Sonth Africa are the Aard-varks (Orycteropide), while in India, and some of the Indian Islands, we find Pangolins, or ant-eaters (Manida), which are all members of the same order. They are scarcely known in the northern hemisphere, and then only in its warmest regions; but they have been recently found fossil in Upper Miocene beds in Samos by Dr. Forsyth-Major.

The well-known examples of Amphibia, confined to Notogaza, or the Southern Hemisphere, we have Cystognathide, found in Australia, Tasmania, and South America; and of freshwater fishes, we have the Haplochitonde, or southern salmon, and the sonthern pikes (Galaxiide), families both unknown north of the Equator, occurring in New Zealand, Chili, Patagonia, and the Falkland Islands.

If we turn to plants, and takinggroups that are confined, or nearly so, to the Southern Homisphere we find among the Saxifragect, that $t$ wo of its tribes (Escalloni, consisting of seventeen genera, 
and Cunoniece, with eighteen genera), are confined (almost) to New Calertonia, Australia, Tasmania, New Zealand, the Mascarene Islands, South Africa, and South America. Of their thirty-five genera two only cross the equator into the northern hemisphere. Of the Proteacea, composed of forty-nine genera and nine hundred and fifty species, only twenty-five species cross the Equator, otherwise they are distributed to all the southern continents with Madagascar, Tasmania, New Zealand, and New Caledonia; but they occur in Miocene and Cretaceous strata in Europe.

Mr. Forbes, after discussing the opinions of Wallace, Darwin, and Blanford for and against an extensive land area in the Antarctic Ocean, remarks :- In considering the number of genera, or species of the same groups that have reached the three terminal regions of the land in the southern hemisphere, it seems almost too remarkable to believe that it should have been the same forms in more than one that have alone been able to survive the vicissitudes of retreat against 'the pressure of more specialised types' through such different lands from the north to the south, without leaving often a single representative north of the equator and yet should have succeeded in resisting being driven right into the southern sea. It is besides a biological axiom that two identical species have never independently arisen in distant localities.

The Author of the paper then proceeded to adduce the evidence brought forward by Huxley in regard to the distribution of the Peristeropodes (of the Gallinacex), and of the Parrots, and that by Prof. W. K. Parker, our most penetrating embryologist, and the foremost of the interpreters of those passing structures in the embryo, which appearing but for an hour, and vanishing as if they had never been, yet so surely proclaim its pedigree and inheritances, in his paper on the Agithognathous birds, in which are described the affinities between (among other groups) the Australian Gymnorhinida and the South American Dendrocolaptida-groups unknown north of the equator.

This evidence, he considers, of the weigbtiest kind in support of the hypothesis that there existed a large land extension round the South Pole joining South America and Australia, and approaching to, or intermittently only connected with, South Africa, possessing a genial climate, on which the progenitors of these groups common to Australia and South America, which have now lost their nearest relations, could multiply, became modifed, and eventually migrated northward on the return of colder epochs, or on account of the subsidence of the land.

Before considering how far the presence of such an austral continent would explain the distribution of life, Mr. Forbes referred to the climate of the southern hemisphere during the later geological periods. He referred to the evidences of glaciation in South Africa, in South America, in Australia, and in New Zealand, dating from a comparatively recent epoch. Mr. Forbes accepted Sir Robert Ball's emphatic declaration: "It is an essential doctrine of the astronomical theory of the ice age that the respective glaciations of the two 
hemispheres were not simultaneous,' but were alternate. And 'if it could be shown that the ice ages in the two hemispheres were concurrent, the astronomical doctrine would have to be forthwith abandoned.' This glacial age, of which evidences have been found in the southern continents, must, if Sir Robert Ball's assertion be correct, have taken place during a genial period in the northern hemisphere. Now during the Miocene age there was such a warm period (doubtless due to a period of high eccentricity) when a luxuriant flora flourished in the Arctic regions to within $8 \frac{1}{2}^{\circ}$ of the Pole.

"The outlines of this Antarctic continent it is of course impossible to trace with anything approaching to accuracy till we are in possession of a larger number of soundings. But it is not unlikely that the great meridional masses of land-or world ridges-which are probably of primeval antiquity extended to meet prolongations running northward from the Antarctic continent. There is some evidence that the direct union of the Antarctic continent with South Africa was not for so prolonged a period as with the others. The presence of the Aphanapteryx and other ocydromine birds both in Mascarenia and in Antipodea supports other evidence pointing to an extension of that area south by Marion and Kerguelen Islands, and of New Zealand south, by way of the Macquarrie, Auckland, and Antipodes Islands. It is interesting to observe that the great Pacific trongh to the east of the longitude of New Zealand extends far south into the Antarctic land."

Mr. Forbes next discussed the evidence derivable from the flora of the islands in the Antarctic Ocean, and argued that it also indicated a more extensive land in those seas.

Mr. Forbes's conception of the form of this Antarctic continent is thus described:- "The Geological evidence shows that New Zealand was separated from Australia during all the Tertiary period, and that East and West Australia existed as two islands during a portion of the Cretaceous and 'Tertiary ages; so that in the early 'Tertiary period, at least, there were three separate islands, West Australia, East Australia, and New Zealand, the two latter with southem extensions. The New Zealand eastern shore-line extended not improbably from the Chatham Islands, by Young Island, to Victoria Land, where the Pacific trough runs far to the south, and northwest from the Chatham Islands, by Norfolk Island, near to-and, perhaps, including-New Caledonia and Fiji; southwards, by Lord Howe's Island to the west of Stewart and Macquarrie Islands, where turning south and westward, it united with the eastern shore of East Australia, prolonged south to the Antarctic Land; its northern extension probably connecting the Great Papuasian Land (New Guinea, the Solomons, New Britain, and New Ireland) across Torres Straits - West Australia at this period, and for a long time previously and after, remaining a large and isolated island. The western shore of East Australia then ran southward and westward to Wilkes Land, where, about the longitude of $90^{\circ} \mathrm{E}$., the trough of the Indian Ocean extends south towards the Pole, once more trending northward by 
Kemp Island, and Kerguelen Land to join the Ethiopian region, either by the Mascarene Island-continent, with perhaps an African commissure, or, perhaps, for a time with that continent directly. The South Atlantic Ocean would seem to extend far south into the Antarctic separating the Ethiopian prolongation from the South American enlargement, which included the Falkland Islands, South Georgia, and the Sandwich Group, to Graham and Alexander Lands. But our knowledge of the sea floor south of Africa is still very imperfect."

"If it be true that Ice Ages and Genial Ages were alternate in the two hemispheres, as Sir R. Ball affirms, then when the Miocene Southern Ice Age was at its height, the life in this southern continent would be driven towards or across the equator, and when in the late Miocene and in the Pliocene, the warm period (corresponding to the growing cold period of the northern hemisphere) was advancing, and the land surface fit for peopling was increasing, there would be a slow return to the Antarctic land. Whether or not there was such a cold period, there must have succeeded a very mild age-almost certainly during the height of the glacial age of the northern hemisphere-to enable the fauna and flora now common to the terminal areas of the three great continents to develop on a southern land and to intermingle."

"The monotremes and marsupials in Australia are supposed by Mr. Wallace to have come to Western Australia at a very ancient period from Asia, via a land connection across the Java Sea, and to have entered East Australia only in the Tertiary age after the union of the two islands. Nearly all our fossil remains, however, of these groups are found in East Australia, and their present distribution is in northern Austro-Malaya and Australia. Now there have been found in Patagonia, as already stated, in early Eocene times fossil remains, nearly allied to the carnivorous Thylacine of Tasmania and the dasyures, that occur both in Pliocene and Pleistocene beds in Australia, or live now in Australia and Tasmania. No fossil remains of these southern forms have been found elsewhere out of Australia and Patagonia. It is not therefore at all improbable to suppose that the South American Thylacine-like forms multiplied and developed in the Southern Continent during the warm age of the southern-and reached East Australia from that continent, then spread north through Tasmania into New Guinea and the Papuan Islands. Why they are not found in New Zealand is difficult to say; some temporary subsidence or other barrier may probably have prevented their reaching it. It does seem to me strange if the marsupials reached Australia viâ the Java Sea, Timor, and the belt of the Austro-Malayan Islands to the west of it, that with the exception of a cuscus, which may not improbably bave been introduced, there are no marsupials in any of the SouthEastern Austro-Malayan Islands, where there are no enemies not found in New Guinea and Australia, especially in Iimor, which is so Australian in its climate and vegetation. The ancestors of the present marsupials in South America, which have no near 
affinity with the present Australian forms, came no doubt via North. America from Europe. The ancestors of the cassowaries, moas, and kiwis are supposed by Mr. Wallace to have come from New Guinea in to the north of East Australia, and to have spread thence to New Zealand in Cretaceous times. Again the Eocene of Patagonia has produced the remains of giant struthious birds-Brontornis burmeisteri-which can have been the ancestors on the Antarctic Continent, not only of the Australian and New Zealand forms, but of all the tridactile forms-of the Apyornis of Madagascar, as well as the Neotropical rheas. Recent remains of AEpyornis received at the British Museum show in the tibia, or leg bones especially, a very close resemblance to that of the moa. The metatarsi of the moa and Apyornis also show many points in common. The Madagascar, the Australian, and the New Zealand Ostricbes would at least seem to have had a common ancestor."

"That a current of life has flowed from south to north, as well as vice versa $a$, has strong support lent to it by the results of Sir William Macgregor's recent botanical collections in New Guinea. In the highland vegetation of that country, along with an extensive display of heaths and whortleberries-forms of vegetation which are scanty in Australia - there is also a marked preponderance of far southern types, belonging to Australia, New Zealand, and Antarctica. In Borneo also have been found plants common to the Papuan highlands, and also plants from high southern latitudes. So many plants from high sonthern latitudes of conmon origin, typical of Tasmania, of continental Australia, of the Southern Ocean, and of Patagonia, point to a land connection of portions of New Guinea with an Antaretic continent. As there are, moreover, abundant evidences of great volcanic action over all the region, in New Zealand, Sonth America, Mascarenia, and the Antaretic Islands, the permutations and combinations of the ups and downs of these lands, the openings and closings of the gates, paths, or stepping stones, are beyond onr computation."

Mr. Forbes sums up in these words:-

Shortly, therefore, 'it is highly probable,' as Mr. Blanford says, 'that many forms of terrestrial life ... originated in the sonthern hemisphere; and ... it is far from improbable that the Antarctic continent was the original area of development.' It seems to me, therefore, highly probable that Professor Huxley's divisions of the Globe, in which he is followed by Professor Kitchen Parker, according to the distribution of life into a northern and into a southern land-an arctogoea and a notogœe-will turn out to be the two fundamental biological divisions of the Globe. That there was a centre of development at both poles, and the wanderings and migrations of the fauna and flora, north wards or sonthwards, from age to age, and from one side of the Equator to the other, were regnlated by glacial and genial periods, and from east to west by the elevation and subsidence of an extensive land, in the sonthern. hemisphere as in the northern.

These deductions as to an Antarctic continent, made on biological. 
grounds, are supported by the depth of the circumpolar sea, so far as it is known. The submarine shelf of the Austral land slopes. northward all round the shores of the known lands more gently than along any other coast, and would seem to indicate that, if elevated, the land would form in great extent a continuation of the three primal ridges of the globe southward, coalesced and spread ont round the Pole, with, between these arms, the terminations of the great and permanent ocean troughs. How far these hypotheses may be substantiated or refuted by future researches it is difficult to say; but the discovery of Aphanapteryx bones on the Chatham Islands must always remain an important fact in the solution of this most difficult and intricate question."

II.-The Supposed Quaternair and since Submerged Volcano of Mrgaleina, at Naples. ${ }^{1}$ By Chev. W. P. Jurvis, F.G.S., ete.

$0^{\mathrm{N}}$ $\mathrm{N}$ entering the Bay of Naples by steamer the first thing which must have struck every geologist-leaving aside Vesuvius for the present-is the line of flat-topped hills stretching along the northern shores of the Bay, from Cape Posillipo to the Chiatamone, above the Castel dell'Uovo, their summits in no place exceeding from 160 to 200 metres in height, except at the Castel Saint'Elmo $(224 \mathrm{~m}$.) while they extend inland from the Vomero to the culminating point at the old Camaldoli convent, above Pianura (455m.). These hills are essentially constituted of irregular strata of ochreousyellow volcanic tufa of various tints, passing on the one side to pale yellowish white, and on the other to yellowish brown. This tufa is accompanied by frequent alternating beds of extremely fine volcanic ashes, and others often exclusively formed of impure-white or ash-grey pumice in angular pieces, ranging from less than a quarter-of-an-inch to several inches across, and adhering slightly together, though easily separated by the hand. Fragmentary pumice also exists in a certain proportion as a constituent of the volcanic tufa itself, in such case partaking in general of the coloration of the rock in which it is imbedded, being of a yellowish brown, and only in some places white, for instance near Piedigrotta. Sometimes the pumice is dark yellowish-brown, this variety, as well as the paler kind, being much decomposed, or what might be called in ordinary language rotten, so as to crumble when an attempt is made to detach it from the enclosing rock, for it is only when the pumice retains its original whitish or ash-grey appearance that it preserves. any consistency or is of any economic value.

It will be immediately observed, on the most superficial examination, how remarkably irregular is the bedding of even the thickest. strata, as they rapidly thin out, and often disappear altogether, to be replaced by others of very different lithological structure. As if to add to such irregularity, the dip of the beds is very varying and inconstant; in one spot it appears to be horizontal, a few yards beyond it is not unfrequently undulating, and further on inclined

${ }^{1}$ From the "Mediterrancan Naturalist," October 1, 1592. 
at a high angle-suggesting the probability of upheaval and givingway of the strata through local volcanic agency, exerted at a very slight depth below the surface and frequently repeated.

In quarrying the tufa as a building-material, invaluable on account of its cheapness (five pieces of a roughly parallelopipidal shape, together measuring about two cubic feet, being worth only a franc) - the greatest difference is found to exist in the coefficient of resistance to pressure and crushing strain, according to the locality and series of beds whence the stone is procured. One point, however, is found in common; it was all bedded as a littoral deposit and in shallow sea-water; in confirmation of this, large oyster shells may be sometimes met with in it. Lead-grey volcanic tufa is largely developed at the southern entrance to the Bay of Naples, around Sorrento, but it is nowhere to be met with on the north side of Vesuvius, or beyond the region $I$ am describing in the direction of Pozzuoli or in the islands of Procida or Ischia.

Topographically the tufa bills of Posillipo and Naples continue in the direction of the old Camaldoli convent, in which neighbourhood scoriaceous and other lava is largely developed; in other directions these hills have no connection with any others, for towards Vesuvius and in the direction of Caserto they die off gradually, and the plain at their foot is but slightly above the sea-level. From Cape Posillipo as far as the Vomero, above the Grotta di Pozzuoli, the hill is saddle-shaped, with a long, narrow ridge at the summit, and sloping down at a considerable angle on each side to the base. At the distance of half-a-mile from the mainland beyond Cape Posillipo is the little islet of Nisita, $180 \mathrm{~m}$. bigh, which is simply a small volcanic cone, with a crater broken down on the side looking towards the entrance of the bay, the rock consisting of volcanic tufa.

It has always beeu a question to me whence this prodigious mass of tufa overlooking the Bay of Naples was ejected. Certainly not from Vesuvius or Monte Somma, far less from certain other volcanoes, such as the Solfatara, the Astruni, or Agnana, which have not the least topographical connection with the hills of which I am speaking, and no denudation has taken place to authorize such a supposition; most improbably also from Nisita, which, besides its insignificant proportions, occupies too eccentric a position. For my part I have for many a long year been led to believe that this tufa was produced by a volcano situated at a short distance from the Mergellina (part of Naples), but now submerged and no longer recognizable. Possibly we may be shortly able to clear up this difficulty, a most unexpected discovery having been recently made in the very heart of Naples, and one to which I am led to attribute considerable geological importance.

At the present time a large main sewage drain is being driven through the soft tufa rock from the south-eastern part of the city to the vicinity of Fuorigrotta, outside the city to the north-west. Under the Villa Montfort, at the lower end of the Parco Grifeo, - close to the Corso Vittorio-Emanuel, the sewer is situated at the level of $13 \mathrm{~m} .70 \mathrm{~cm}$. above the sea; $250 \mathrm{~m}$. farther north, close to 
the new International Hospital, it is slightly more than $13 \mathrm{~m}$. above the sea-level; the surface of the ground above being respectively $100 \mathrm{~m}$. and $65 \mathrm{~m}$. at the points alluded to. Just under the Villa Montfort trachyte rock was met with, $40 \mathrm{~m}$. of it having been already bored through, while at the surface not a trace of such rock was ever suspected to exist, volcanic tufa alone being seen; nor did it ever come under any person's observation that trachyte should anywhere be met with in the tufa hills I am describing. The trachyte, which I have carefully examined, is of a dark lead-grey or bluish colour, and equal to the hardest and most compact kind found in any part of the Phlegræan Fields, being identical in structure to some met with at Pozzuoli, and like it enclosing sinall crystals of sanidine or glassy felspar. Attiguous to the trachyte, and for a certain distance from it to the south-east, the tufa is very pumiceous, and large loose blocks of trachyte of a yellowish tinge are to be found imbedded in the midst of the tufa, from which they do not essentially differ in colour. Sometimes the tufa adheres firmly to the trachyte, which might lead us to suppose that the latter must have fallen on the surface of the tufa before it had had time to be perfectly cooled. M. Giusti, the engineer in charge of the works at this point, kindly gave me the following data. After leaving the ordinary yellow tufa common to these hills, some beds of good yellow tufa were pierced, then rather clayey tufa; after which dark-yellow tufa containing large fragmentary pieces of undecomposed pumice, a variety peculiar to this neighbourhood; then a gentle synclinal of white tufa, each of these several beds being but a few metres in thickness. After this followed $30 \mathrm{~m}$. of pumiceous tufa, containing large loose blocks of trachyte, followed by the trachyte rock in situ above alluded to.

Have we not here the evilence of the existence of a volcanic eruption of Quaternary age, though it cannot yet be decided whether it ever reached the surface, or whether there were not some lateral veins, or a blind dyke, which forced its way up through the already existing tufa. The subject offers much interest, and I hope some day to be able to communicate further information regarding it. I am led to conclude that the central crater of this volcano must have been situated within a mile of the present coast-line in a spot now occupied by deep water, the cone having subsided since the Quaternary period. Should my conjecture be found admissible we might apply the name of "Mergellina volcano" to this trachytic ejection, and we might then be anthorized to regard the tufa hills of Naples and Posillipo as having had their origin thence. Both the trachyte and the yellow tufa are rocks common to all the volcanoes of the Phlegræan Fields and the neighbouring islands, while leucitic rocks characterize Monte Somma, and angite and leucite Vesuvian rocks.

While speaking of the neighbourhood of Naples I may just give the results of a few very careful observations I made this spring of the temperature of several thermal springs and fumaroles, and compare them with former studies.

Casamicicola, Island of Ischia.-Acqua del Gurgitello, February $1869,84^{\circ}$. c. (Jervis); 10th May, $1892,84^{\circ}$. c. (Jervis). 
Lacco Ameno, Island of Ischia.-Acquadella Rita 1833, $70^{\circ}$. c.

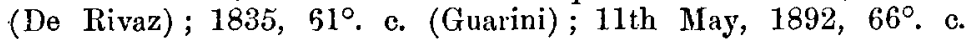
(Jervis).

Barano d'Ischia.-Fumarola di Saint' Angelo, on the beach; February $1869,100^{\circ}$ e. (Jervis); 11th May, 1892, $100^{\circ}$. c. (Jervis).

Casamicicola.-Stufe or Fumarole di Castiglione 1822, upper fumarole $56^{\circ}$. c. lower fumarole $66^{\circ}$. c. (Del Giudice); 11th May, 1892, lower fumarole $56^{\circ}$. c. (Jervis).

Pozzuoli-Fumarola della Bocca della Solfatara, February 1862, $93^{\circ}$. 4-96 $6^{\circ}$. 5 c. (Deville) ; June $1865,77^{\circ}-96^{\circ}$. c. (Deville); $1865,96^{\circ}$. c. (Fouqué) ; July 1867, 115 . c. (Gorceix); January $1869,92^{\circ}$. c. (Jervis); 12 May, 1892, 95․ c. (Jervis).

Naples._Stufe di San Germano, 1856, 64\%.-93\%. c. (Deville); 1857 and $1882,61^{\circ} .-97^{\circ}$. c. (Deville); 1857 and $1862,61^{\circ} .-97^{\circ}$. c. (Deville); July $1869,85^{\circ} .-96^{\circ}$. c. (Deville); May 1892, 86 . c. (Jervis).

Naples.-Acqua del lago prosciugato di Agnana, May, 1892, $69^{\circ} .-73^{\circ}$. according to place (Jervis).

Naples. -Grotta del Cane, May 1892, $38^{\circ}$. c. (Jervis).

Turin, September, 1892.

\section{EEPORTS AIND PEOCEFDINGS.}

\section{Grological Societr of London.}

I.-March 22nd, 1893.-W. H. Hudleston, Esq., M.A., F.R.S., President, in the Chair. The following communications were read :--

1. "On the Jaw of a new Carnivorous Dinosaur from the Oxford Clay of Peterborough." By R. Lydekker, Esq., B.A., F.G.S.

The Anthor describes a fragment of the left side of a lower jaw of a Camivorons Dinosaur from the Oxford Clay of Peterborongh, indicating a new genus and species, which he names Sarcolestes Leedsi.

2. "On a Mammalian Incisor from the Wealden of Hastings." By R. Lydekker, Esq., B.A., F.G.S.

In this paper a small rodent-like tooth from the Wealden of Hastings, belonging to Sir Joln Evans, K.C.B., is described. It is probably the front tooth of one of the mammalian genera found in the Purbeck Beds, as may be gathered from American specimens.

3. "On an Intrusion of Muscovite-biotite-gneiss in the Southeastern Highlands, and its accompanying Thermo-metamorphism." By George Barrow, Esq., F.G.S., of the Geological Survey. (Communicated by permission of the Director-General of the Geological Surrey.)

The area to which this papers refers lies in the north-eastern part of Forfarslire, and is drained by the two Esks. The Anthor first describes the distribution, mode of occurrence, and petrological characters of the intrusive masses. In the north-western portion of the area the intrusive rock is always a gneiss, and occurs in thin tongues which permeate the surrounding rocks. Towards the south- 